\title{
Viability of Nitrogen Fertilization in Pastures
}

\author{
Estevam Matheus Costa*1, Gabriel Ribeiro Mendes ${ }^{2}$, Matheus Vinícius Abadia Ventura ${ }^{1}$, Camila Franco \\ Buiatti Souza $^{3}$, Leandro Spíndola Pereira ${ }^{1}$ and Vinicius Martins Soares ${ }^{4}$ \\ ${ }^{1}$ Goiano Federal Institute, Rio Verde, Brazil \\ ${ }^{2}$ Northern University of Paraná, Brazil
}

${ }^{3}$ University Center of Triangle, Brazil

${ }^{4}$ University of the State of Minas Gerais, Brazil

*Corresponding author: Estevam Matheus Costa, Goiano Federal Institute, Rio Verde, Brazil

\begin{abstract}
ARTICLE INFO
Received: 恝 March 25, 2019

Published: April 02, 2019

Citation: Estevam Matheus C, Gabriel Ribeiro M, Matheus Vinícius Abadia V, Camila Franco Buiatti S, Leandro Spíndola P, Vinicius Martins S. Viability of Nitrogen Fertilization in Pastures. Biomed J Sci \& Tech Res 16(4)-2019. BJSTR. MS.ID.002890.
\end{abstract}

Keywords: Forage Yield; Nitrogen Response; Grazing
ABSTRACT

Nitrogen fertilization in pastages has as main function the increase of forage productivity. The objective was to evaluate the financial viability of nitrogen fertilization in pastures. Through the bibliographic survey it was evident the importance of nitrogen fertilization for pasture activities and for the dissemination of nitrogen fertilization in the pastures is economically viable. However, the economic viability varies according to several factors, such as a forage species, is an expected response of the animals that feed this forage and fertilizer. It can be stated that the viability varies according to the fertilizer used, urea or ammonium sulphate, the price per kg of $\mathrm{N}$ applied and mainly the dosages applied, since a good part of the work found that dosages between 100 and/or 150 $\mathrm{kg}$ of $\mathrm{N}$ ha-1 are economically viable, whereas dosages higher than these are no longer feasible even though the forage still responds to fertilization with increased productivity and quality.

\section{Introduction}

The cerrado is the main beef producing region of Brazil, with most of this production coming from extensive breeding systems. In this region, livestock farming has low rates of animal productivity and low economic returns. This is due, among other factors, to the inadequate management of the soil-plant-animal system, as for example, the lack of interest of the producers in performing soil correction and maintenance fertilization. Pasture recovery is one of the ways to reverse the current forage situation in Brazil and one of the ways to achieve this goal is to work with the reconstitution of soil fertility, depleted by successive years of extractive exploitation. According to Martha \& Junior, the grasses of the genus Brachiaria occupy growing spaces in Brazilian livestock due to their high adaptability to edaphoclimatic conditions, however despite presenting a great productive potential, they are still used in extensive regimes without due attention to the pasture management as maintenance correction and soil fertility. According to Nicolella, Brazil has the fourth largest world fertilizer market.
However, what determines the price of this input is the cultivated area, prices of agricultural products and cost of credit.

Nitrogen is the nutrient whose function is to stimulate the vegetative growth of plants mainly by adding coloration and rapid growth. According to Alvim and Brotel, in the 1980s nitrogen fertilization has a great advantage when it is carried out in plants that have a high production potential. According to Aguiar, in the 1980s the best economic return on nitrogen fertilization was 150 $\mathrm{kg} / \mathrm{ha}$ per year and at the beginning of the current decade it was $419 \mathrm{~kg}$ nitrogen per year. In this way, the objective of this work is to demonstrate, in a conscious and objective way, the viability and the cost of production of nitrogen fertilization in pastures.

\section{Development}

\section{Situation of Brazilian Pastures}

The beef and veal sector are of great importance for national agribusiness and places the country in an international position as 
the largest meat producer and sixth largest dairy producer in the world (USDA, 2014).

Brazil has more than 180 million hectares of pasture land, native and cultivated and is considered the simplest and most economical way to feed cattle. Countries that use the feedlot system as the basis for meat production (the USA, Australia and several European countries) need manpower, machinery and fuels to feed animals, while in Brazil this is made predominantly by the animal itself, through grazing (Dias-Filho, 2011). The extensive system of animal exploration, very characteristic in Brazil, can be conducted, with relative success, using little input, technology and labor.

That is, in livestock it is possible to produce, although with low efficiency (Dias-Filho, 2014). As a result, in Central Brazil, it is estimated that $80 \%$ of the cultivated pastures, responsible for more than $55 \%$ of the national meat production, are in a degradation stage, directly affecting the sustainability of livestock (Peron; Evangelista, 2004). Reduced pasture productivity over time (grazing degradation) is one of the major obstacles to the establishment of agronomic, economic and environmentally sustainable livestock farming. Among the causes that explain the degradation of pastures in the Cerrado, the low fertility of the soil, due to the lack of fertilization, assumes a prominent position (Martha-Junior; Vilela 2002). Panicum maximum is considered the main forage species of the Brazilian market. It is adapted to light soils, from medium to high fertility and recommended for more intensive livestock farming systems, due to its high productivity [1].

\section{Colonião Grass Productivity (Panicum Maximum)}

Plants of the genus Panicum belong to the family Poaceae, subfamily Panicoideae and tribe Paniceae, possessing about 81 genera and more than 1460 species. They are characterized by a great morphological and physiological variability of their representatives, being P. maximum Jacq. the main representative species of the genus in Brazil, due to its great importance for animal production (Corsi \& Santos 1995). This grass is a perennial, clumpforming crop with a height varying from 60 to $200 \mathrm{~cm}$, leaves wider than the ends and panicles 12 to $40 \mathrm{~cm}$ high [1]. The most popular cultivars are Tanzania and Mombasa, occupying the second and third place in the commercialization of forage seeds, respectively (Jank 2008). Grasses of the genus Panicum (i.e. Colonião, Tanzânia and Mombaça), present great adaptability and high productive potential. Grass productivity is reduced in the winter period. Gerdes [3] reported that dry mass production of Tanzania grass was $3.30 \mathrm{t} /$ ha in the spring, $2.88 \mathrm{t} /$ ha in the summer, $2.35 \mathrm{t} / \mathrm{ha}$ in autumn and $1.10 \mathrm{t} / \mathrm{ha}$ in the winter.

The grass colonium presents high productivity when compared to other tropical forages. In his studies, Pedreira (1972) observed higher dry matter production of grass colonies when compared to three other tropical grasses (Jaraguá e Taiwan), obtaining a higher rate of growth during the rainy season, reaching values around 60 kg dry matter /ha/dia. The pastures formed by grasses of this genus are characterized by aggressiveness, good capacity to support grazing and fire. It is widely accepted by animals in the green state that is their main route of use (Alcântara and Bufarah 1978).

\section{Pasture Fertilization}

During the 1970s, livestock production expanded throughout the Brazilian territory, mainly due to the low cost of land acquisition, credit facilities and the introduction of forage species (pastures) with a high capacity to adapt to the climate and low fertility of soils (Peron \& Evangelista 2004). The productivity of forages is due to the production of biomass, which will define the support capacity of the pasture. This contribution of biomass is a response of plants to soil fertility, associated with the time, frequency and interval between cuts [4]. The application of nutrients, especially nitrogen, in adequate quantities, is a fundamental practice when increasing the production and quality of the forage. For Monteiro [5], under normal edaphoclimatic conditions and with no other limitation, the supply of $\mathrm{N}$ is the factor that has the greatest impact on the productivity of the well established forage plant and the animals that use it.

\section{Productivity}

One of the main problems in low productivity of tropical pastures is nitrogen deficiency, which results in a marked fall in support capacity and in animal gain [6]. The production of dry matter, according to Alcântara e Bufarah, depends on the level of soil fertility, varying between 8 at $13 \mathrm{t} / \mathrm{ha}$ of dry matter. Therefore, in order to intensify the use of pastures, the correct fertilization program is among the main determinants of production and quality (Freitas, 2007). The pastures are formed by a community of tillers, so that the net production of the forage accumulation is the result of seasonal fluctuations in the number of tillers in the area, which when associated with foliar growth and senescence processes in individual tillers, indicate the accumulation of grass forage [7]. According to Benitez [8], the density of tillers is a good indicator of forage production, especially when they are allied to the production of vigorous and well-nourished tillers, producing, therefore, a greater number of leaves per tiller. Several studies have demonstrated the influence of the nutritional status of the forage plant on tillering and on other attributes such as leaf area (Lavres Júnior \& Monteiro 2003).

The relation blade/stem is a characteristic of great importance for the feeding of cattle. Leaf blades are the preferred constituents of the forage plant and of greater importance in the nutrition of ruminants, because they have a higher nutritional quality compared to stems in a mature stage [9] (apud Quadros 2001). One of the factors that represent the loss of nutritional quality of forage grass is the increase of the stem/leaf ratio with the maturation of the pasture, because the leaves do not lose nutritive value as quickly as the stems, as well as maintains a better digestibility (Granato 2013 and apud Corsi 1990). 


\section{Nutritional Quality}

The crude protein content, acid detergent fiber, neutral detergent fiber, dry matter digestibility in vitro, among others, are indicative of the nutritional quality of a grass [8]. Among these, the crude protein content is considered as one of the main components, since this variable can directly or indirectly affect the voluntary consumption of dry matter and, consequently, the production of meat [10]. The concentration of nitrogen directly affects the crude protein content in the plant. That is, under conditions of low nitrogen availability in the soil, the plants present a decrease in their growth reducing the crude protein content, being able to render the forage of low nutritive value to produce meat [11]. Barbosa et al. Freitas et al. observed effects of nitrogen fertilization on the bromatological composition of the Mombaça grass, testing the doses of 0, 200, 400 and $600 \mathrm{~kg}$ ha-1, in the form of urea and a cut-off interval of 35 days, in order to verify that the crude protein levels increased from nitrogen fertilization levels and that the highest levels occurred in the $600 \mathrm{~kg}$ ha- 1 .

\section{Sources of Nitrogen}

In Brazil, the most commercialized sources of nitrogen used for pasture fertilization are urea and ammonium sulfate. They represent more than $90 \%$ of the market, with urea being the most used source (Martha Júnior et 2004). The use of these sources has advantages and disadvantages. Urea is distinguished by the lower cost per kilogram of $\mathrm{N}$. However, from the agronomic point of view, it presents limitations in the surface applications, due to the losses of $\mathrm{N}$ by volatilization. On the other hand, ammonium sulphate presents lower losses of $\mathrm{N}$ by volatilization when applied to acid soils, besides being a source of sulfur, although it presents higher cost per kilogram of N (Teixeira Filho 2010) [12]. Studies carried out by Costa et al. [13] demonstrated the influence of the use of different sources of nitrogen on dry matter production in Marandu grass. They observed that ammonium sulphate resulted in higher dry mass production than urea.

\section{Discussion}

When discussing the financial viability of nitrogen fertilization in pastures, it should be considered that factors such as fertilizer used, dosage and freight are factors that can strongly influence the viability of nitrogen fertilization. Lopes et al. [14], concluded that from the dose of 150 to $300 \mathrm{~kg}$ of $\mathrm{N}$ ha-1, the values of the economical viability of the fertilization decreased, and that in this way, even though the nitrogen fertilization is still viable until the dosage of 300 of $\mathrm{N}$ ha-1, the economic feasibility of fertilization in dosages greater than 100 of $\mathrm{N}$ ha-1 decreases. Restle et al. [15], evaluating animal productivity and the economic return of nitrogen fertilization with urea and ammonium sulphate on black oats and ryegrass pastures, concluded that the two sources of nitrogen did not influence animal performance and forage production. The price of nitrogen $\mathrm{kg}$ should be the main factor to consider when deciding which fertilizer to use.
In a work carried out by Lopes et al. [14], demonstrated the viability of nitrogen application in Brachiaria brizantha pastures at doses of 100 to $300 \mathrm{~kg}$ of $\mathrm{Nha}-1$, however the dosage that represented the maximum economic viability was $100 \mathrm{~kg}$ of $\mathrm{N}$ ha- 1 . Euclides et al. [16] concluded that nitrogen fertilization in the dosage of 100 $\mathrm{kg}$ of $\mathrm{N}$ ha-1 in two applications, one at the beginning of summer and another in March, of $50 \mathrm{~kg}$ of $\mathrm{N}$ ha-1 in each application has a significant and efficient effect on pasture productivity. Nitrogen fertilization contributes to the improvement of soil physical and chemical properties and improved grazing. In this way, nitrogen fertilization is not restricted to short-term benefits, for example in raising productivity, but can promote benefits in long term [11]. Vitor et al. [17] observed that nitrogen fertilization increased linearly elephant grass production up to the dose of $700 \mathrm{~kg}$ ha-1, this can be explained due to the greater availability of the forage is due to a higher amount of nitrogen, inferring on the enzymatic activities and physiological in the plant.

The greater presence of chlorophyll is demonstrated in plants with higher availability of nitrogen, which is related in the photoassimilates production, which influences the characteristics of the plant [18]. In the work of Mariane, observed that the productivity of forage Panicum maximum cv. MG12 Paredão increased linearly as a function of nitrogen fertilization, where the fertilization of 200 $\mathrm{kg} / \mathrm{ha}$ presented higher yield. Studies have shown that nitrogen fertilization has considerably increased the dry matter yield of forages [19-23] (Mariane 2018). When working with the cultivar Mombaça, Factori et al. [24] observed that the $300 \mathrm{~kg}$ dose of nitrogen per ha provided a higher mass yield. Porto [25], in their work with three cultivars of brachiaria submitted to nitrogen fertilization, observed that Piatã grass presented higher forage yield compared to other cultivars (Marandu and Xaraés), being that the cultivars Piatã and Xaraés were the ones that presented greater amount of leaves, that is an indicator of production and quality of grass forage.

In the work of Porto et al. [26], the Buffel grass cv. PI 295658 presented higher dry matter yield in relation to Buffel grass cv. Aridus, which, in turn, is superior to Buffel grass cv. Grass, being that it complements, that the dose of $225 \mathrm{~kg}$ ha- 1 of $\mathrm{N}$ provided the highest yield through the dry matter of the Buffel grass. The advantage of nitrogen fertilizer application, as well as the final increase in forage, is perceptible. The efficient use of pasture with good management becomes a priority, aiming to increase yield due to the application of nitrogen fertilization [27-42].

\section{Conclusion}

The performance of nitrogen fertilization is feasible both from the agronomic point of view, since it favors the good development of the forage, as well as from the economic point of view, since it is applied in a rational way in order to maximize the investment.

\section{References}

1. Andrade, Rodrigo Duarte (2009) Características estruturais e produtivas das cultivares marandu e xaraés adubadas com nitrogênio e potássio 
em diferentes intervalos após o corte. 38 f. Dissertação. (Mestrado) Departamento de Produção Vegetal, Universidade Federal dos Vales do Jequitinhonha e Mucuri, Diamantina, 2009.

2. Balsalobre Marco AA, Santos Patricia Menezes (2002) Avaliação econômica da adubação nitrogenada em pastagens. POINT Milk.

3. Banzatto DA, Kronka SN (1995) Experimentação agrícola. (3 ${ }^{\text {rd }}$ edn.). Jaboticabal: FUNEP, pp. 247.

4. Benett CGS, Buzetti S, Silva KS, Bergamaschine AF, FABRICIO, JA (2008) Produtividade e composição bromatológica do capim-marandu a fontes e doses de nitrogênio. Ciência e Agrotecnologia 32(5): 1629-1636.

5. Benitez MH (1993) Influência do manejo sobre a produção e qualidade do capim aruana (Panicum maximum Jacq. cv. Aruana) colhido em três estratos verticais. Trabalho apresentado à Faculdade de Ciências Agrárias e Veterinárias - UNESP - Campus de Jaboticabal, para graduação em Zootecnia.

6. Bonfim Silva EM (2005) Nitrogênio e enxofre na recuperação de capim- braquiária em degradação em neossolo quartzarênico com expressiva matéria orgânica. 123 f. Tese (Doutorado)- Escola Superior de Agricultura "Luiz de Queiroz", Universidade de São Paulo, Piracicaba.

7. Castagnara DD, Zoz T, Krutzmann A, Uhlein A, Mesquita EE, et al. (2011) Produção de forragem, características estruturais e eficiência de utilização do nitrogênio em forrageiras tropicais sob adubação nitrogenada. Semina: Ciências Agrárias 32(4): 1637-1648.

8. Colozza MT, Kiehl JC, Werner IC (2000) Produção de matéria seca, concentração de nitrogênio e teor de clorofila em Panicum maximum cv. Aruana adubado com nitrogênio. In: reunion latinoamericana de producion animal, 16., congresso uruguayo de producion animal, 3., 2000, Montevideo. Anais... Montevideo: Asociacion Latinoamericana de Producion Animal.

9. Corsi M, Nascimento D (1986) Princípios de fisiologia e morfologia de plantas forrageiras aplicados no manejo das pastagens In: peixoto AM, Moura JC, Faria VP (Eds.), Pastagens: fundamentos da exploração racional, Piracicaba, p. 1-10.

10. Costa KAP, Faquin V, Oliveira IP (2010) Doses e fontes de nitrogênio na recuperação de pastagens do capim-marandu. Arquivo Brasileiro de Medicina Veterinária e Zootecnia 62(1): 192-199.

11. Euclides, Valéria Pacheco Batista (2007) Eficiência biológica e econômica de pasto de capim-tanzânia adubado com nitrogênio no final do verão. Pesquisa Agropecuária Brasileira 42(9): 1345-1355.

12. Marco AF, Paulo CGS, Daniel MG, Antenor SN, Carlo HZ Maratti, et al. (2018) Produtividade de massa de forragem e proteína bruta do capim mombaça irrigado em função da adubação nitrogenada. Colloquium Agrariae, p. 49-57.

13. Fernandes JC (2011) Fontes e doses de nitrogênio na adubação do capim- mombaça em cerrado de baixa altitude. Dissertação (Mestrado) - Faculdade de Engenharia de Ilha Solteira, p. 51.

14. Freitas KR, Rosa B, Rugierro JA, Nascimento JL, Heineman AB, et al. (2007) Avaliação da composição químico-bromatológica do capimmombaça (Panicum maximum Jacq.) submetido a diferentes doses de nitrogênio. Biosci J 23: 1-10.

15. Granato TP (2013) Avaliação nutricional e da produtividade de diferentes acessos de Panicum maximum presentes no Banco Ativo de Germoplasma do IZ. Dissertação (Mestrado) - APTA, Instituto de Zootecnia, p. 74.

16. Gerdes L (1999) Algumas Características Agronômicas, Morfológicas e de Valor Nutritivo dos Capins Marandu, Setária e Tanzânia. Dissertação (Mestrado) - Universidade de São Paulo. Faculdade de Medicina Veterinária e Zootecnia, p. 82.

17. Gimenes Flávia Maria de Andrade(2011) Ganho de peso e produtividade animal em capimmarandu sob pastejo rotativo e adubação nitrogenada. Pesquisa Agropecuária Brasileira 44(7): 751-759.
18. Jank L (1994) Potencial do Gênero Panicum. In: Simpósio brasileiro de forrageiras e pastagens, Campinas. Anais... Campinas: Colégio Brasileiro de Nutrição animal, p. 25-31.

19. Lavres J, Monteiro FA (2002) Combinações de doses de nitrogênio e potássio para a produção e nutrição do capim-mombaça. Boletim de Indústria Animal 59(2): 102-114

20. Lopes MA, Katia Feltre, A Donizette De Oliveira, Evangelista Antônio Ricardo (2013) Manejo e viabilidade econômica da adubação nitrogenada em Brachiaria brizantha cv. Marandu. Archivos Latinoamericanos de Producción Animal 21: 159-162.

21. Macedo MCM (2000) Sistemas de produção animal em pasto nas Savanas Tropicais da América: Limitações à Sustentabilidade. In Reunião Latinoamericana de Produccion Animal,16. Congreso Uruguayo de Produccion Animal, 3 Montevidéu.

22. Mariani Leonardo, Lucas Pereira Martins, Rodrigo LM Silva, Adilson Amorim Brandão, Vinicius RF Dalmolin (2018) Produtividade da forrageira panicum maximum cv. mg12 paredão submetido a diferentes níveis de adubação nitrogenada e de diferentes fontes. Connectionline 18.

23. Mazza LM, Pôggere GC, Ferraro FP, Ribeiro CB, Cherobim VV, et al (2009) Adubação nitrogenada na produtividade e composição química do capim-mombaça no primeiro planalto paranaense. Scientia Agraria 10(4): 257-265

24. Monteiro FA (1995) Nutrição mineral e adubação. In: Simpósio sobre manejo da pastagem FEALQ pp. 219-244.

25. Moreira FLM, Mota FOB, Clemente CA, Azevedo BM, Bomfim GV (2006) Adsorção de fósforo em solos do Estado do Ceará. Revista Ciência Agronômica 37(1): 7-12.

26. Pedreira JV (1972) Crescimento estacional dos capins colonião (Panicum maximum Jacq.), gordura (Melinis minutiflora Pal de Beauv), Jaraguá (Hyparrhenia rufa (Ness) Stapf), e pangola de Taiwan A-24 (Digitaria pentzii, Stent). Dissertaçao de Mestrado. Escola Superior de Agricultura "Luiz de Queiroz", Piracicaba.

27. Porto Edson Marcos Viana (2017) Produção de biomassa de três cultivares do gênero Brachiaria spp. submetidos à adubação nitrogenada. Agropecuária Científica no Semiárido 13(1): 9-14.

28. Porto Edson Marcos Viana, DD Alves, Cláudio MT Vitor, M Ferreira da Silva, Carollayne Gonçalves Magalhães et al. (2017) Produção de biomassa de cultivares do capim buffel submetidos à adubação nitrogenada. Unimontes Científica 19(1): 122-129.

29. Primavesi AC, Primavesi O, Corrêa LA, Silva AG, Cantarella H (2006) Nutrientes na fitomassa de capim-Marandu em função de fontes e doses de nitrogênio. Ciência e Agrotecnologia 30(3): 562-568.

30. Restle João (2000) Produtividade animal e retorno econômico em pastagem de aveia preta mais azevém adubada com fontes de nitrogênio em cobertura. Revista Brasileira de Zootecnia 29(2): 357-364

31. Rocha PG, Evangelista AR, Lima JA, Rosa B (2002) Adubação nitrogenada em gramíneas do Gênero Cynodon. Ciência Animal Brasileira, Goiânia 3(1): 1-10.

32. Rodrigues RC, Mattos HB, Pereira WLM (2004) Perfilhamento do capim braquiária cultivado em solo proveniente de uma pastagem degradada em função de doses de enxofre, nitrogênio e calcário. Boletim de Indústria Animal 61(1): 39-47.

33. Rosado TP (2013) Efeito da aplicação de fontes e doses de nitrogênio nos atributos químicos do solo, na extração de nutrientes e na produção do capim- mombaça. Dissertação (Mestrado) - Universidade Federal do Espírito Santo, p. 75.

34. Sbrissia AF, Sila Carneiro da Silva, Domicio do Nascimento, Lilian Elgalise Techio Pereira (2009) Crescimento da Palnta Forrageira: Aspectos Relativos ao Acúmulo e Valor Nutritivo da Forragem. 25옹 Simpio sobre Manejo da Pastagem. Piracicaba, FEALQ, pp. 278. 
35. Silva DJ, Queiroz AC (2002) Análise de alimentos (métodos químicos e biológicos). ( $3^{\text {rd }}$ edn.). Viçosa: UFV, pp. 235.

36. Silva FAS, Azevedo CAV (2009) Principal Components Analysis in the Software Assistat-Statistical Attendance. American Society of Agricultural and Biological Engineers, p. 22-24.

37. Sniffen CJ, O'Connor JD, Van Soest PJ, Fox DG, Russell JB (1992) A net carbohydrate and protein system for evaluating cattle diets: II. Carbohydrate and protein availability. J Anim Sci 70(11): 3562-3577.

38. Skerman PJ, Riveros F (1992) Gramíneas tropicales. (2 ${ }^{\text {nd }}$ Edn.). Roma: FAO, pp. 849

\section{ISSN: 2574-1241}

DOI: 10.26717/BJSTR.2019.16.002890

Estevam Matheus Costa. Biomed J Sci \& Tech Res

(C) 9 This work is licensed under Creative Commons Attribution 4.0 License

Submission Link: https://biomedres.us/submit-manuscript.php
39. (2018) USDA. USDA Foreign Agricultural Service.

40. Valle CB, Jank L, Resende RMS (2009) 0 melhoramento de forrageiras tropicais no Brasil. Revista Ceres 56: 460-472.

41. Vitor CMT, Fonseca DM, Cóser AC, Martins CE, Nascimento D, et al. (2009) Produção de matéria seca e valor nutritivo de pastagem de capim-elefante sob irrigação e adubação nitrogenada. Revista Brasileira de Zootecnia, Viçosa 38(3): 435-442.

42. SILVA Alex Santos Lopes da (2018) Carta Insumos - Custo para formação de um hectare de pasto. Consultoria.

$\begin{array}{ll}\text { BIOMEDICAL } & \text { Assets of Publishing with us } \\ \text { RESEARCHES } & \text { - Global archiving of articles } \\ & \text { - Immediate, unrestricted online access } \\ & \text { - Rigorous Peer Review Process } \\ \end{array}$

